\title{
Simultaneous GC-MS Determination of Free and Bound Phenolic Acids in Slovenian Red Wines and Chemometric Characterization
}

\author{
Milena Ivanović, ${ }^{1}$ Maša Islamčević Razboršek ${ }^{1}$ and Mitja Kolar ${ }^{2, *}$ \\ ${ }^{1}$ University of Maribor, Faculty of Chemistry and Chemical Engineering, Smetanova ulica 17 SI-2000 Maribor, Slovenia \\ ${ }^{2}$ University of Ljubljana, Faculty of Chemistry and Chemical Engineering, Večna pot 113 \\ SI-1000 Ljubljana, Slovenia \\ * Corresponding author: E-mail: mitja.kolar@fkkt.uni-lj.si \\ Tel.: (+386)-1-4798-694
}

Received: 20-04-2016

\begin{abstract}
Several phenolic acids (PAs), caffeic, vanillic, syringic, p-coumaric and ferulic acid, found in Slovenian red wines were studied using gas chromatography and mass spectrometry. For isolation of the PAs from wine samples, solid phase extraction using hydrophilic modified styrene - HLB cartridges was used. The bound PAs were extracted after basic hydrolysis and $o$-coumaric acid was used as the internal standard. The developed method was validated and the linear concentration range for all analytes was from 1 to $100 \mathrm{mg} \mathrm{L}^{-1}$ with correlation coefficients above 0.999 . We show that the method is repeatable (RSD $<2 \%$ ), recoveries were above $96 \%$, and LOD and LOQ values were acceptable.

In all of the wine samples tested, caffeic and $p$-coumaric acid were determined to be the predominant PAs (17-72 mg $\mathrm{L}^{-1}$ ), while other compounds were found in lower concentrations. Principal Component Analysis and Cluster Analysis were used to study differences between wines related towards varieties and Slovenian wine regions. The results demonstrate that variety has more influence on PAs content than wine regions in Slovenian red wines.
\end{abstract}

Keywords: Phenolic acids, Slovenian red wines, gas chromatography, mass spectrometry, PCA, CLU

\section{Introduction}

Antioxidant activity of plant materials and natural products has received a great deal of interest over the past years both in the public and scientific communities. ${ }^{1-4} \mathrm{Ge}$ nerally, it is believed that consumption of plant phenolics decreases the risk of diseases related to oxidative stress. ${ }^{5}$

Wine, as a complex matrix containing several hundreds of different chemical compounds, ${ }^{6,7}$ presents an analytical challenge, especially for identification and quantification of compounds in low concentrations. The chemical composition of red wines includes minerals, vitamins, proteins, sugars and phenolic compounds, among them PAs. Red wines are considered to have more protective function than white or rosé wines, because of their higher content in antioxidant substances released from the grape skin and seeds. ${ }^{8}$ The total amount of polyphenols in red wines has been estimated in the range from 2000 to $6000 \mathrm{mg} \mathrm{L}^{-1} .9$ Polyphenols are usually responsible for wi- ne colour and contribute to the bitter flavour of wine. ${ }^{10}$ From the literature it is known that lactic acid bacteria $(\mathrm{LAB})$ are responsible for the occurrence of malolactic fermentation (MLF), a secondary fermentation which is considered to be beneficial in most red wines. ${ }^{11}$ The phenolic acids content of grapes and wines can positively or negatively affect the rate of MLF. ${ }^{12}$ For example, gallic acid at low concentrations has stimulatory effects on the growth and malolactic activity of LAB. ${ }^{13}$ On the other hand, some phenolic acids, especially those from the hydroxycinnamic class, delayed the conclusion of the malolactic fermentation by these bacteria. ${ }^{14}$ Hydroxycinnamic acids (particularly $p$-coumaric acid) are also known to inhibit growth of a variety of microorganisms including wine-spoilage strains of $L$. collinoides, L. brevis and L. hilgardii. ${ }^{15}$

Although Slovenia is a small country, its wine production has a significant role in the economy. Altogether, 22,000 hectares of vineyard area is divided among three 
major regions (Drava Valley-Podravje, Lower Sava Valley-Posavje and the Littoral-Primorska) with further division into sub-regions. ${ }^{16,17}$ The Slovenian Littoral is Slovenia's most widely known and prominent wine region of both white and red wines. Slovenian vineyards are planted with different vine varieties, including Merlot, Cabernet Sauvignon, Chardonnay, Pinot Noir, Syrah, Barbera, and many others.

PAs are present in their free forms or as glycosylated and esterified derivatives. ${ }^{18-20}$ Acidic, basic and enzymatic hydrolysis are the most commonly used methods for the extraction of PAs from natural materials. ${ }^{21-25}$ From the scientific literature it is obvious that the most commonly used techniques for the determination of PAs are high-performance liquid chromatography (HPLC) with UV or DAD detection or liquid chromatography coupled with mass spectrometry (LC-MS). ${ }^{26-29}$ Because of the longer sample preparation process for analysis, using gas chromatography with mass spectrometry (GC-MS) in analysis of phenolic compounds is relatively rare, but in comparison with the other methods mentioned, GC-MS offers several advantages, including complete and high-resolution separation, sensitive detection, unambiguous identification and quantitation of a wide range of phenolics (including all isomers) in one chromatographic run. ${ }^{30-32}$

The aim of our study was to develop a simple and quantitative extraction method of selected PAs to ensure clean extracts in order to obtain a much more sensitive, selective and accurate GC-MS method for identification and quantitation of both free and bound PAs in red wine samples. For extraction of target compounds from the wine samples, solid-phase extraction (SPE) using hydrophilic modified styrene (HLB) cartridges was used. The bound PAs were determined after basic hydrolysis using $\mathrm{NaOH}$ in the presence of L-ascorbic acid and EDTA as stabilizers. The applicability of the developed method was tested on Slovenian red wines. Statistical and chemometric analyses were performed and the wines were classified.

\section{Experimental}

\section{1. Chemicals}

All reagents and solvents used were minimally of analytical purity. Standard compounds, trans-caffeic acid (99\%), vanillic acid (97\%), syringic acid (97\%), trans-pcoumaric acid (98\%), trans-o-coumaric acid (98\%) and trans-ferulic acid (98\%) and solvents, tetrahydrofuran-THF (99.5\%) and pyridine (99.9\%), were supplied by Merck (Germany). Derivatization reagent $N$-Methyl- $N$-(trimethylsilyl)trifluoroacetamide (MSTFA), HPLC-grade methanol $(\mathrm{MeOH})$ and sodium hydroxide- $\mathrm{NaOH}(99 \%)$ were purchased from Sigma (USA). GC-grade toluene (99.5\%) and hydrochloric acid-HCl (36.5\%) were purchased from Carlo Erba (Italy). Dichloromethane-DCM was purchased from JT Baker (Germany), L-ascorbic acid (99.7\%) was purcha- sed from Alkaloid (Macedonia) and EDTA was purchased from Kemika (Croatia). The water used was obtained from a Milli-Q water purification system.

\section{2. Preparation of Standard Solutions and Calibration Curves}

Standard stock solutions of caffeic acid, vanillic acid, syringic acid, $p$-coumaric acid and ferulic acid, as well as of $o$-coumaric acid (ISTD) were prepared by accurately weighing $10 \mathrm{mg}$ of each into a $10 \mathrm{ml}$ volumetric flask, and then dissolving in THF. Five calibration standard solutions were prepared by combining various volumes of PAs stock solutions with $50 \mu \mathrm{l}$ of ISTD in a $50 \mathrm{~mL}$ conical glass flask. Each solution was derivatized by treating it with $100 \mu \mathrm{L}$ of MSTFA and $50 \mu \mathrm{L}$ of pyridine for 1 $\mathrm{h}$ at $80^{\circ} \mathrm{C}$ in a sand bath. After derivatization was finished, TMS derivatives were quantitatively transferred to 1 $\mathrm{mL}$ flasks and filled up to the mark with toluene. Five calibration standard solutions in concentration range from 1 to $100 \mathrm{mg} \mathrm{L}^{-1}$ were injected in triplicates. The calibration curves were constructed by linear regression of the peakarea ratio of individual PA standard to the ISTD (y), versus the concentration $\left(\mathrm{mg} \mathrm{L}^{-1}\right)(\mathrm{x})$.

\section{3. GC-MS Instrumentation and Working Conditions}

TMS derivatives of PAs were analyzed with a Varian 3900 gas chromatograph (GC), coupled to MS/MS Saturn 2100 ion trap mass spectrometer. GC separation was performed using a Varian capillary column VF-5ms CP8944 $(30 \mathrm{~m} \times 0.25 \mathrm{~mm}$, with the stationary phase $0.25 \mu \mathrm{m}) .1$ $\mu \mathrm{L}$ of the sample was injected in split mode (split ratio 1:10). Carrier gas was He (6.0 UHP) at a flow rate of 1.0 $\mathrm{mL} \min ^{-1}$. The initial oven temperature was $40{ }^{\circ} \mathrm{C}$, held for $1 \mathrm{~min}$, and then the temperature was raised to $320^{\circ} \mathrm{C}$ at a rate of $10^{\circ} \mathrm{C} \mathrm{min}^{-1}$, and finally, held for $3 \mathrm{~min}$. The total run time was $32 \mathrm{~min}$. The injection-port and transfer-line were set to $250{ }^{\circ} \mathrm{C}$ and $170{ }^{\circ} \mathrm{C}$, respectively. Mass spectra were recorded in SCAN or SIM mode in a range from 50 to $650 \mathrm{~m} / \mathrm{z}$ using electron ionization energy at 70 $\mathrm{eV}$. Peak identification was done by comparing retention times $\left(t_{\mathrm{R}}\right)$ and spectral properties with those of standard compounds or by library matching from NIST MS library containing the mass spectra of TMS derivatives of PAs.

\section{4. Validation Parameters for the GC-MS Method}

The method was validated for linearity, precision as repeatability, limit of detection (LOD) and limit of quantitation (LOQ). For linearity determination, all calibration curves were constructed using the internal standard method. The curves were fitted to linear least-squares regression. The precision was evaluated through the within-day 
(WD) and between-days (BD) repeatability, and expressed as relative standard deviation (RSD). The limit of detection (LOD) was calculated using the equation $\left(3.3+\mathrm{s}_{\mathrm{y}}\right) / \mathrm{b}_{1}$ and the limit of quantitation (LOQ) was calculated from the equation $\left(10+s_{y}\right) / b_{1}$ (where $s_{y}$ is standard deviation of linear regression and $b_{1}$ is slope of the calibration line). ${ }^{33}$

\section{5. Wine Samples}

The developed method was tested using Slovenian red wine samples. Twelve red wines from different Slovenian wineries and different varieties were purchased from local supermarkets. All the tested wine samples orginated from four vintages (2011-2015). Table 1 shows the varieties, wineries, year of production and percentage of alcohol. Wines were stored in a refrigerator at the temperature of $+4{ }^{\circ} \mathrm{C}$ until analyzed.

\section{6. Preparation of the Wine Samples and Optimization of the Extraction Procedure}

\section{6. 1. Extraction of Free PAs}

A standard solution of PAs mixture (in a concentration of $1000 \mathrm{mg} \mathrm{L}^{-1}$ ) was prepared in $\mathrm{MeOH}$. Solutions of PAs mixture in synthetic wine (hydroalcoholic solution of $5 \mathrm{~g} \mathrm{~L}^{-1}$ tartaric acid, $12 \%$ of ethanol, and $\left.\mathrm{pH} 3.2\right),{ }^{34}$ were prepared by pipetting 30 and $100 \mu \mathrm{L}$ of standard solution, respectively, in a $10 \mathrm{~mL}$ volumetric flask, and diluted with synthetic wine up to the mark. $1 \mathrm{~mL}$ of each solution was transferred into a $50 \mathrm{~mL}$ conical flask, spiked with $50 \mu \mathrm{L}$ of ISTD (1000 $\left.\mathrm{mg} \mathrm{L}^{-1}\right)$, diluted with $1 \mathrm{~mL}$ of ultra-pure water and acidified with $6 \mathrm{M} \mathrm{HCl}$ to a pH value of 2. Prepared samples were added to pre-conditioned HLB Supel- co ${ }^{\circledR}$ SPE cartridges $(3 \mathrm{~mL}, 60 \mathrm{mg}$ stationary phase made from hydrophilic modified styrene). A schematic procedure of the sample extraction is shown in Table 2.

The free PAs fraction was eluted with $2 \times 2 \mathrm{~mL}$ of THF. The eluate was collected and dried in a rotary evaporator (at $40{ }^{\circ} \mathrm{C}$ ) to absolute dryness. Then the sample was derivatized by adding $100 \mu \mathrm{l}$ of MSTFA and $50 \mu \mathrm{l}$ piridine, heated at $80{ }^{\circ} \mathrm{C}$ for $1 \mathrm{~h}$, diluted with toluene, and analyzed by GC-MS. The analyses were carried out in triplicate. The accuracy of the extraction process was determined through the recovery value in $\%$ of the PAs.

Table 2. Sample extraction by SPE (using HLB Supelco ${ }^{\circledR}$ cartridges).

\begin{tabular}{ll}
\hline Sample extraction by SPE \\
\hline 1. & pre-washing of cartridge with $2 \times 2 \mathrm{~mL} \mathrm{DCM}$ \\
2. & column conditioning: $2 \times 2 \mathrm{~mL}$ of $\mathrm{MeOH}$ and $2 \times 2 \mathrm{~mL}$ \\
& acidified water $(\mathrm{pH}=1-2)$ \\
3. & sample application: $2 \mathrm{~mL}$ of the acidified sample \\
4. & column washing: $2 \times 2 \mathrm{ml}$ ultra-pure water \\
5. & elution: $2 \times 2 \mathrm{ml} \mathrm{THF}$ \\
\hline
\end{tabular}

For the determination of free PAs in selected red wines, the samples were prepared according to the same procedure. $1 \mathrm{~mL}$ of homogenized wine sample was spiked with $50 \mu \mathrm{L}$ of ISTD, diluted with $1 \mathrm{~mL}$ of ultra-pure water and acidified with $6 \mathrm{M} \mathrm{HCl}$ to a $\mathrm{pH}$ value of 2 , followed by the previously described steps.

\section{6. 2. Alkaline Hydrolysis of PAs}

The stability of the compounds and their recovery percentage after alkaline hydrolysis was first determined

Table 1. Characteristics of the analyzed wine samples.

\begin{tabular}{|c|c|c|c|c|c|c|}
\hline $\begin{array}{l}\text { Sample } \\
\text { code }\end{array}$ & Variety & $\begin{array}{l}\text { Variety } \\
\text { code }\end{array}$ & Winery & $\begin{array}{l}\text { Wine } \\
\text { region }\end{array}$ & $\begin{array}{c}\text { Year of } \\
\text { production }\end{array}$ & $\begin{array}{c}\% \\
\text { alcohol }^{*}\end{array}$ \\
\hline$\overline{\mathrm{SW} 1}$ & Cabernet Sauvignon & 1 & „Vina Koper“ & Primorska & 2014 & 13 \\
\hline SW2 & Modra Frankinja & 2 & „Stari Hram“ & Posavje & 2014 & 10.5 \\
\hline SW3 & Cabernet-Sauvignon & 1 & „Vipava““ & Primorska & 2014 & 11 \\
\hline SW4 & Modri Pinot (Pinot noir) & 2 & Štajerska Slovenia-Ptuj & Podravje & 2011 & 12.5 \\
\hline SW5 & Cabernet Sauvignon & 1 & Goriška Brda & Primorska & 2013 & 12.5 \\
\hline SW6 & Refošk & 3 & Srednje Škofije & Primorska & 2014 & 11 \\
\hline SW7 & Refošk & 3 & „Vina Koper“ & Primorska & 2014 & 12.5 \\
\hline SW8 & Modra Frankinja & 2 & Štajerska Slovenia-Ptujska Klet & Podravje & 2011 & 11.5 \\
\hline SW9 & $\begin{array}{l}\text { Modri Pinot } \\
\text { (Pinot Noir) }\end{array}$ & 2 & „Vipava“ & Primorska & 2013 & 12 \\
\hline SW10 & Portugalka & 3 & Bela Krajina & Posavje & 2015 & 11 \\
\hline SW11 & $\begin{array}{l}\text { Cabernet } \\
\text { Merlot }\end{array}$ & 1 & $\begin{array}{l}\text { Jeruzalem- } \\
\text { Ormož }\end{array}$ & Podravje & 2013 & 12.5 \\
\hline SW12 & $\begin{array}{l}\text { Metliška } \\
\text { Črnina }\end{array}$ & 2 & Bela Krajina & Posavje & 2012 & 11.5 \\
\hline
\end{tabular}

\footnotetext{
*According to the declaration on the wine bottle.
} 
with the standard compounds and later an optimized procedure was used on the real wine samples. Standard solution of PAs mixture (at a concentration of $1000 \mathrm{mg} \mathrm{L}^{-1}$ ) was prepared in $\mathrm{MeOH}$. Solutions of PAs mixture in synthetic wine were prepared by pipetting 30 and $100 \mu \mathrm{L}$ of standard solution, respectively, into the $10 \mathrm{~mL}$ volumetric flask, and diluted with the synthetic wine up to the mark. $1 \mathrm{~mL}$ of each solution was transferred into a $50 \mathrm{~mL}$ conical flask, spiked with $50 \mu \mathrm{L}$ of ISTD, and exposed to alkaline hydrolysis, according to the previously described method with some modifications. ${ }^{35} 1 \mathrm{~mL}$ of the spiked synthetic wine was treated by adding $9 \mathrm{~mL}$ of $2 \mathrm{M} \mathrm{NaOH}$ (which contained 1\% L-ascorbic acid and $10 \mathrm{mM}$ EDTA as stabilizers) for $2 \mathrm{~h}$ at room temperature. Then the sample was acidified to $\mathrm{pH} 2$ using $6 \mathrm{M} \mathrm{HCl}$, and PAs were extracted with SPE HLB cartridges. The whole procedure with alkaline hydrolysis was repeated also without stabilizers.

\section{7. Quantitation of PAs}

The contents of free and total PAs were determined from the corresponding calibration curves using the ISTD method, taking into account the recovery of the extraction procedure. PAs from the cinnamic group exist in transand cis-forms, both found in plants. Trans-forms of PAs are naturally predominant isomers. Therefore, for quantitative determination, the peak areas of the trans- and cis- forms of caffeic acid, $p$-coumaric acid and ferulic acid were summed.

\section{8. Statistical Analysis}

Chemometrical data analysis was carried out in order to discover any statistically or other significant differences between the samples grouped according to two categorical variables - wine variety and wine region. Microsoft Excel was used for the data preparation and result outputs. Statistical data treatment was performed using SPSS Statistics version 22.

\section{Results and Discussion}

Our study tested isolation and quantitative determination of five target PAs (caffeic acid, vanillic acid, syringic acid, $p$-coumaric acid and ferulic acid) in red wine samples using the GC-MS method. All GC-MS SCAN parameters for trimethylsilylated standard compounds, together with their retention times $\left(t_{\mathrm{R}}\right)$ and characteristic fragment ions, are listed in Table 3.

Linear regression analysis proved that the responses for all of the investigated compounds were linear over the tested concentration range (1-100 $\left.\mathrm{mg} \mathrm{L}^{-1}\right)$, and correlation coefficients $\left(r^{2}\right)$ were above 0.999 . The results of the regression analysis and calibration data are shown in Table 4. Table 4

Table 3. Retention times and fragmentation parameters for trimethylsilylated PAs obtained after trimethylsilylation using the ion-trap mass detector.

\begin{tabular}{lcl}
\hline Compound & $\mathbf{t}_{\mathbf{R}}$ & $\begin{array}{l}\text { Characteristic fragmentation ions } \boldsymbol{m} / \boldsymbol{z} \\
\text { (relative intensity } \%)\end{array}$ \\
\hline cis- $\boldsymbol{o}$-Coumaric acid & 16.65 & $147(100), 293,308$ \\
Vanillic acid & 17.70 & $253,267,282,297(100), 312$ \\
cis- -Coumaric acid & 17.94 & $219,249,293(100), 308$ \\
trans- $\boldsymbol{o}$-Coumaric acid & 18.18 & $147,219,293(100), 308,381$ \\
Syringic acid & 19.11 & $298,312,328,342(100)$ \\
cis-Ferulic acid & 19.32 & $249,293,308,323,338(100)$ \\
trans- -Coumaric acid & 19.49 & $219,250,293(100), 308,381$ \\
cis-Caffeic acid & 19.99 & $219,381,396(100), 397$ \\
trans-Ferulic acid & 20.95 & $249,293,323,338(100)$ \\
trans-Caffeic acid & 21.38 & $73,219,381,396(100)$ \\
\hline
\end{tabular}

Table 4. Validation parameters for investigated PAs.

\begin{tabular}{llcccc}
\hline PA & Linear correlation & $\boldsymbol{r}^{\mathbf{2}}$ & ${ }^{\mathbf{1}}$ WD-RSD & ${ }^{\mathbf{2}}$ BD-RSD & LOD* $^{*}$ LOQ $^{*}$ \\
\hline Vanillic acid & $\mathrm{y}=0.0477 \mathrm{x}+0.0771$ & 0.9999 & 0.11 & 0.72 & 0.05 \\
Syringic acid & $\mathrm{y}=0.0231 \mathrm{x}+0.0921$ & 0.9999 & 0.95 & 1.81 & 0.06 \\
$p$-Coumaric acid & $\mathrm{y}=0.0398 \mathrm{x}+0.0555$ & 0.9996 & 0.38 & 1.47 & 0.06 \\
Caffeic acid & $\mathrm{y}=0.0558 \mathrm{x}+0.0986$ & 0.9999 & 1.36 & 1.97 & 0.07 \\
Ferulic acid & $\mathrm{y}=0.0324 \mathrm{x}+0.0718$ & 0.9996 & 1.01 & 1.81 & 0.03 \\
\hline
\end{tabular}

${ }^{1}$ Within-day PA/ISTD peak-area ratio repeatability of individual PAs at the concentration $10 \mathrm{mg} \mathrm{L}^{-1}$, expressed as \%RSD. ${ }^{2}$ Between-days PA/ISTD peak-area ratio repeatability of individual PAs at the concentration $10 \mathrm{mg} \mathrm{L}^{-1}$, expressed as \%RSD. * LOD and LOQ are in mg L $\mathrm{L}^{-1}$. 
also shows the within-day (WD) and between-days (BD) repeatability expressed as relative standard deviation (RSD), and it gives RSD below $2 \%$ in all cases. The determined values of LODs and LOQs for all selected PAs are also shown in Table 4.

From the literature it is well known that anthocyanintype pigments can cause great interference in the chromatographic separation and identification of non-anthocyanin phenolic compounds. ${ }^{36}$ In our study, anthocyanins were successfully removed using HLB cartridges. Another ad- vantage of HLB cartridges over conventional C 18 columns in the separation of phenolic compounds are that more polar interferences (e.g. sugars) can be eliminated with water without losing analytes, higher sensitivity, good repeatability, reproducibility, and high percentages of recovery were reported by Perez-Magarino et al., 2008. ${ }^{37}$

Accuracy of SPE in determining free PAs was evaluated by spiking a synthetic wine with the standard solution at two different concentrations levels (30 and $100 \mathrm{mg}$ $\mathrm{L}^{-1}$ ). The recovery of free PAs ranged from $93 \%$ to $114 \%$

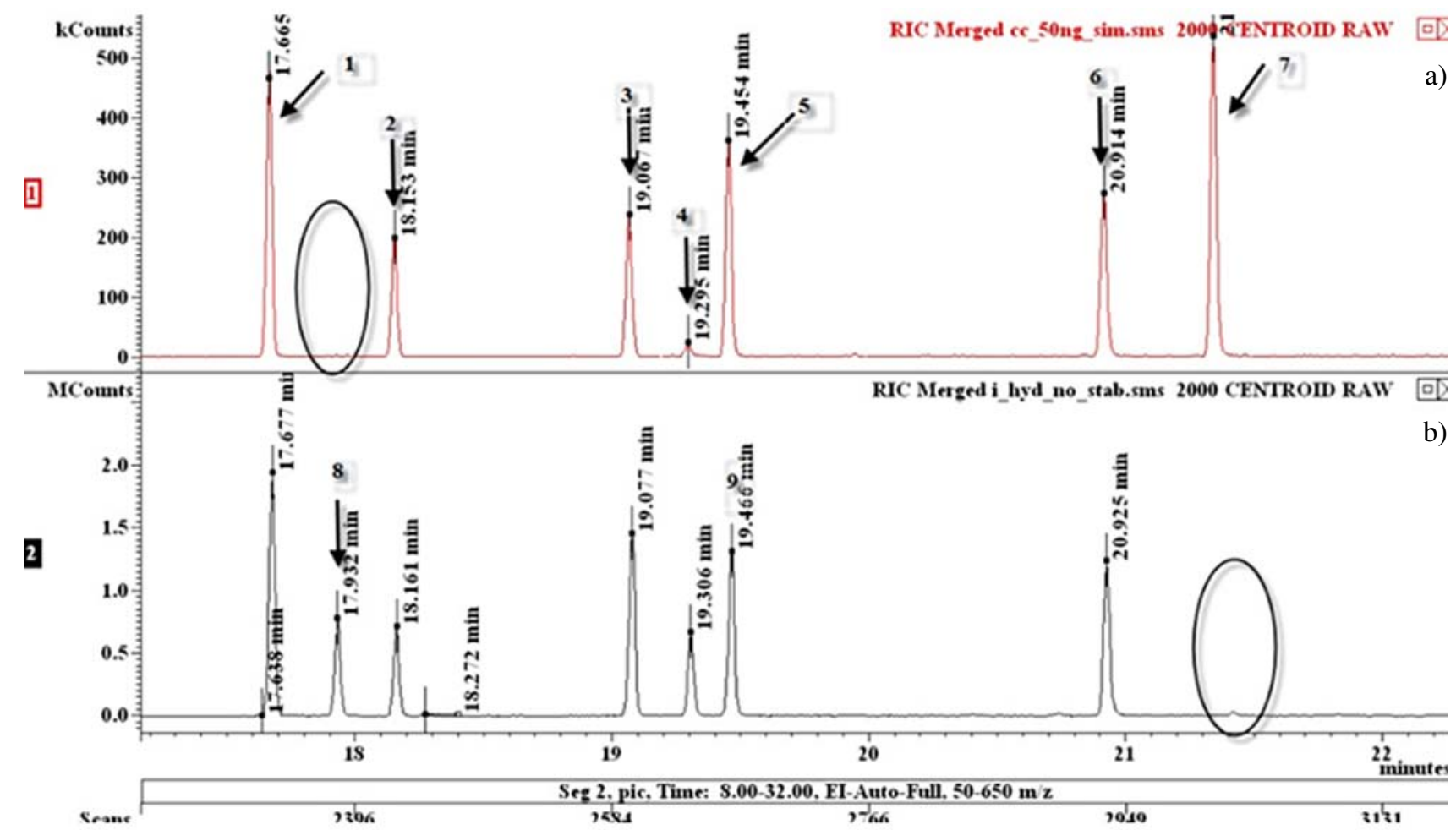

Figure 1. Chromatograms of standard solutions after; a) hydrolysis in presence of stabilizer (1. vanillic acid; 2. trans-o-coumaric acid; 3. syringic acid; 4. cis-ferulic acid; 5. trans-p-coumaric acid; 6. trans-ferulic acid; 7. trans-caffeic acid; 8. cis-p-coumaric acid; cis-caffeic acid (minimal peak at $t \mathrm{R} 19.99 \mathrm{~min}$ ); b) hydrolysis without stabilizer (1. vanillic acid; 2. trans-o-coumaric acid; 3. syringic acid; 4. cis-ferulic acid; 5. trans-p-coumaric acid; 6. trans-ferulic acid; 7. trans-caffeic acid (missing peak); 8. cis-p-coumaric acid.

Table 5. Determination of the method accuracy expressed as recovery $(\%)$.

\begin{tabular}{|c|c|c|c|c|c|}
\hline \multicolumn{6}{|c|}{ Recovery of extraction procedure (\%) } \\
\hline \multirow{4}{*}{ Phenolic acid } & \multirow{2}{*}{\multicolumn{2}{|c|}{ Free PAs }} & \multicolumn{3}{|c|}{ Bound PAs } \\
\hline & & & \multicolumn{2}{|c|}{$\begin{array}{l}\text { In the presence } \\
\text { of stabilizer }\end{array}$} & $\begin{array}{l}\text { Without of } \\
\text { a stabilizer }\end{array}$ \\
\hline & \multicolumn{5}{|c|}{ Concentration $\left(\mathrm{mg} \mathrm{L}^{-1}\right)$} \\
\hline & 30 & 100 & 30 & 100 & 100 \\
\hline Vanillic acid & 105.5 & 98.9 & 114.2 & 105 & 113.7 \\
\hline Syringic acid & 106.8 & 93.6 & 107.5 & 101 & 105.4 \\
\hline$p$-Coumaric acid & 101.7 & 106 & 110.5 & 103 & 135.1 \\
\hline Ferulic acid & 94.5 & 96 & 97.4 & 104.4 & 133.7 \\
\hline Caffeic acid & 102.7 & 106 & 105.9 & 96.32 & $\mathrm{NQ}^{\mathrm{a}}$ \\
\hline
\end{tabular}

${ }^{a}$ NQ-not quantified. Concentration $\left(\mathrm{mg} \mathrm{L}^{-1}\right)<\mathrm{LOQ}$ (for details see Table 4.). 


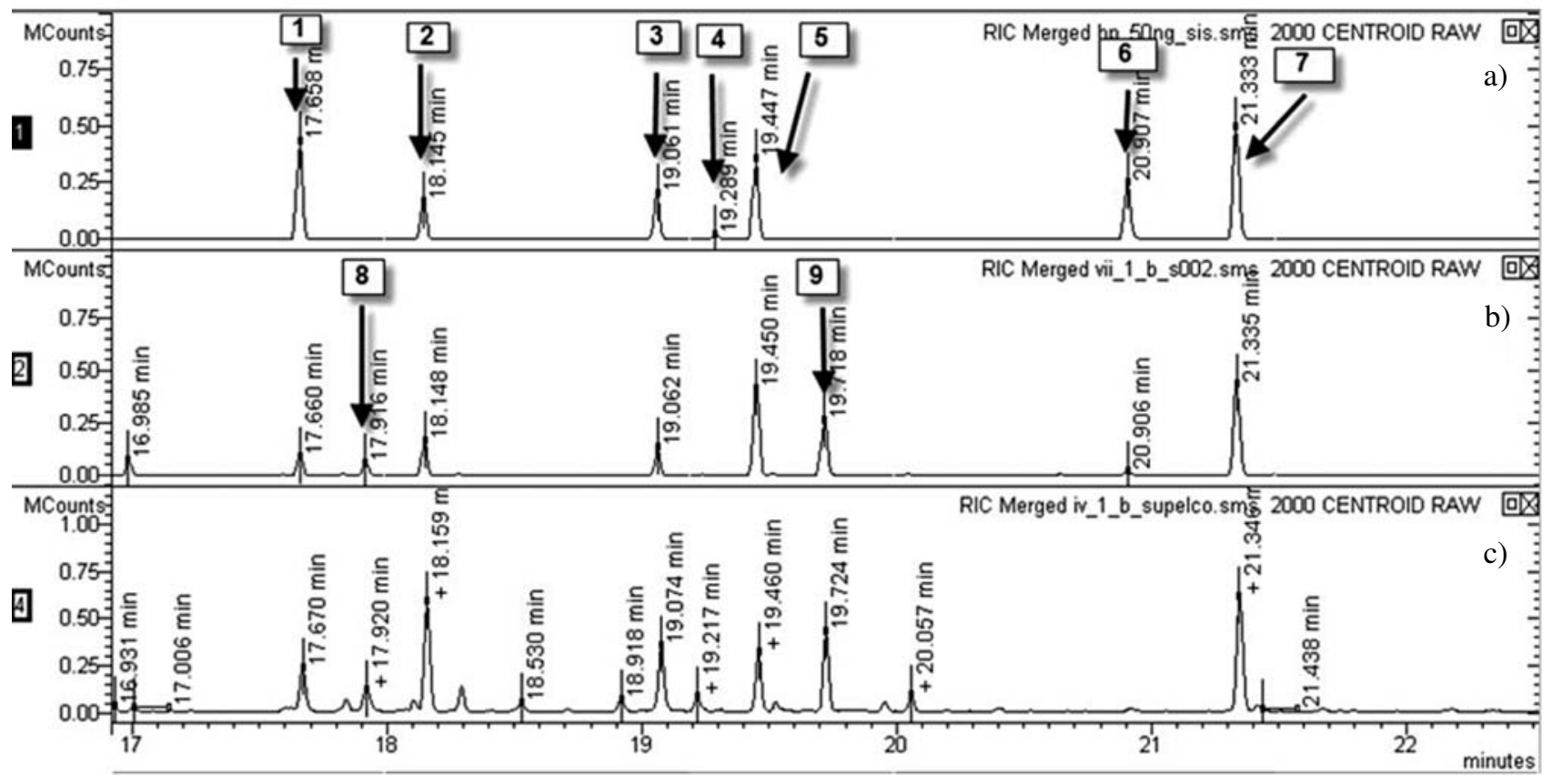

Figure 2. Typical chromatograms of selected PAs recorded in: a) SIM mode of standard mixture; b) SIM mode of red wine extract and c) SCAN mode of red wine extract (1. vanillic acid; 2. o-coumaric acid; 3. syringic acid; 4. cis-ferulic acid; 5. trans-p-coumaric acid; 6. trans-ferulic acid; 7. trans-caffeic acid; 8. cis-p-coumaric acid; 9. L-ascorbic acid (stabilizer)).

Table 6. Content $\left(\mathrm{mg} \mathrm{L}^{-1}\right)$ of free and total PAs in Slovenian red wines.

\begin{tabular}{|c|c|c|c|c|c|c|}
\hline Wine code & Form & Vanillic acid & Syringic acid & $\begin{array}{c}\text { Phenolic acid }^{\mathrm{a}} \\
p \text {-Coumaric acid }\end{array}$ & Ferulic acid & Caffeic acid \\
\hline \multirow[t]{2}{*}{$\overline{\text { SW1 }}$} & Free & $N^{b}$ & $3.7 \pm 0.5$ & $7.7 \pm 0.2$ & $\mathrm{ND}^{\mathrm{c}}$ & $3.2 \pm 0.3$ \\
\hline & Total & $3.8 \pm 0.4$ & $19.8 \pm 0.4$ & $32.6 \pm 0.3$ & ND & $17.1 \pm 0.3$ \\
\hline \multirow[t]{2}{*}{ SW2 } & Free & $1.0 \pm 0.1$ & $3.2 \pm 0.3$ & $0.7 \pm 0.1$ & NQ & $5.4 \pm 0.9$ \\
\hline & Total & $14.5 \pm 2.5$ & $29.8 \pm 3.1$ & $28.1 \pm 2.2$ & $0.1 \pm 0$ & $49.7 \pm 3.2$ \\
\hline \multirow[t]{2}{*}{ SW3 } & Free & NQ & NQ & NQ & NQ & NQ \\
\hline & Total & $5.4 \pm 1.7$ & $14.3 \pm 1.42$ & $37.5 \pm 2.1$ & ND & $17.8 \pm 0.4$ \\
\hline \multirow[t]{2}{*}{ SW4 } & Free & $2.1 \pm 0.2$ & $10.7 \pm 0.2$ & $1.9 \pm 0.1$ & ND & $11.8 \pm 1.2$ \\
\hline & Total & $12.6 \pm 1.9$ & $25.9 \pm 0.5$ & $31.0 \pm 1.1$ & ND & $44.5 \pm 2.0$ \\
\hline \multirow[t]{2}{*}{ SW5 } & Free & $0.9 \pm 0.1$ & $5.1 \pm 0.1$ & $1.6 \pm 0.1$ & ND & $4.0 \pm 0.3$ \\
\hline & Total & $7.3 \pm 0.6$ & $21.9 \pm 2.6$ & $48.4 \pm 0.9$ & ND & $29.3 \pm 0.5$ \\
\hline \multirow[t]{2}{*}{ SW6 } & Free & $1.6 \pm 0.1$ & $4.7 \pm 0.4$ & $0.7 \pm 0.1$ & NQ & $4.8 \pm 0.1$ \\
\hline & Total & $9.5 \pm 1.0$ & $25.2 \pm 2.8$ & $42.8 \pm 3.6$ & $2.5 \pm 0.8$ & $41.0 \pm 0.1$ \\
\hline \multirow{2}{*}{ SW7 } & Free & $2.5 \pm 0.4$ & $3.4 \pm 0.7$ & $1.4 \pm 0.1$ & NQ & $3.6 \pm 0.4$ \\
\hline & Total & $10.3 \pm 1.4$ & $29.9 \pm 3.0$ & $71.9 \pm 0.2$ & $4.9 \pm 0.1$ & $48.1 \pm 1.1$ \\
\hline \multirow[t]{2}{*}{ SW8 } & Free & $3.9 \pm 0.8$ & $4.4 \pm 0.4$ & $2.1 \pm 0.2$ & NQ & $3.5 \pm 0.4$ \\
\hline & Total & $14.6 \pm 1.0$ & $20.0 \pm 0.1$ & $9.5 \pm 0.7$ & NQ & $36.9 \pm 0.5$ \\
\hline \multirow[t]{2}{*}{ SW9 } & Free & $5.1 \pm 0.1$ & $5.6 \pm 0.2$ & NQ & ND & $0.7 \pm 0.0$ \\
\hline & Total & $10.9 \pm 0.6$ & $19.7 \pm 0.3$ & $20.9 \pm 0.1$ & NQ & $38.4 \pm 0.6$ \\
\hline \multirow[t]{2}{*}{ SW10 } & Free & $4.9 \pm 0.3$ & $7.7 \pm 0.3$ & NQ & NQ & NQ \\
\hline & Total & $7.7 \pm 0.8$ & $29.5 \pm 2.2$ & $54.2 \pm 1.2$ & $0.7 \pm 0.1$ & $64.0 \pm 0.6$ \\
\hline \multirow[t]{2}{*}{ SW11 } & Free & $2.0 \pm 0.1$ & $4.6 \pm 0.3$ & $2.9 \pm 0.1$ & ND & $4.1 \pm 0.0$ \\
\hline & Total & $11.8 \pm 0.3$ & $29.7 \pm 2.5$ & $63.1 \pm 0.9$ & ND & $33.7 \pm 0.3$ \\
\hline \multirow[t]{2}{*}{ SW12 } & Free & $6.0 \pm 0.6$ & $10.3 \pm 0.1$ & NQ & NQ & NQ \\
\hline & Total & $14.6 \pm 0.2$ & $27.6 \pm 1.1$ & $47.2 \pm 0.6$ & $0.2 \pm 0.01$ & $64.4 \pm 0.6$ \\
\hline
\end{tabular}

${ }^{a}$ Each value is the mean $\left(\mathrm{mg} \mathrm{L}^{-1}\right)$ of three independent replicates \pm standard deviation.

${ }^{\mathrm{b}} \mathrm{NQ}$-not quantified. Concentration $\left(\mathrm{mg} \mathrm{L}^{-1}\right)<\mathrm{LOQ}$ (for details see Table 4.).

${ }^{\mathrm{c}} \mathrm{ND}$-not detected. Concentration $\left(\mathrm{mg} \mathrm{L}^{-1}\right)<\mathrm{LOD}$ (for details see Table 4.). 
(Table 5.). These results are in agreement with the results reported by other authors. ${ }^{38,39}$ The recovery of the standard compounds after alkaline hydrolysis (without or with stabilizers) extracted by SPE were also determined (Table 5). The results prove that hydrolysis without stabilizers (L-ascorbic acid and EDTA) led to a complete loss of caffeic acid ${ }^{35}$ and promoted isomerization of trans-p-coumaric acid to its $c i s$-form (Figure 1). For all other investigated compounds, the recoveries were above $96 \%$.

The developed method was then used for the determination of selected PAs in twelve Slovenian red wine samples. Figure 2c presents a typical chromatogram of wine extract.

Contents of five different PAs present in red wine samples are shown in Table 6 (mean value \pm sd). From these results it can be concluded that caffeic acid and $p$ coumaric acid are the most important of total PAs, with contents ranging from 17 to $72 \mathrm{mg} \mathrm{L}^{-1}$. In all of the wines investigated, ferulic acid is present at the lowest concentration level. It was measured only in wines from the Posavje region and in two samples from the Primorska region. It is also worth to mention that red wine sample SW12 represents a mixture of red wine varieties Modra Frankinja, Žametovka, Portugalka and Šentlovrentka and therefore is a very specific red wine sample. This fact was confirmed by the obtained results (Table 6) as the contents of all investigated PAs in the sample SW12 were comparable with contents in the samples SW2 and SW10, both of them belonging to varieties Modra Frankinja and Portugalka, respectively. The largest proportion of PAs was present in bound form.

\section{1. Statistical Analysis}

Exploratory data analysis was performed using the SPSS program. In the first step we searched for outliers but no outliers were found in the dataset. Departures from the normal distribution were demonstrated by the Q-Q plots and tested with the Kolmogorov-Smirnov test. Significance value for all tested variables was above 0.05 , which indicates normal distribution of data. The Pearson correlation test ( 0.01 and 0.05 significance levels) was used to determine any inter-relation between two variables. Statistically significant correlations were found only between caffeic acid and syringic acid at the 0.01 level (0.744), and between caffeic acid and vanillic acid at the 0.05 level $(0.592)$.

\section{1. 1. Principal Component Analysis (PCA)}

Principal component analysis (PCA) is an unsupervised multidimensional method used for reducing the number of variables along with preserving the information contained in the data table. Projection of the wines on the first two principal components (accounting for 79.8\% of the total data variability) demonstrates a clear separa- tion according to the wine variety (Figure 3.). The first principal component (PC1) explained $53.7 \%$ of the variation between the samples, and the second (PC2) explained $26.1 \%$ of the variation. Wines from the Cabernet-Sauvignon variety (group 1 on the biplot) were separated from the other samples, and formed a group in the positive part of PC2, while the Modri Pinot variety (group 2 on the biplot) formed a group in the negative part of PC2.

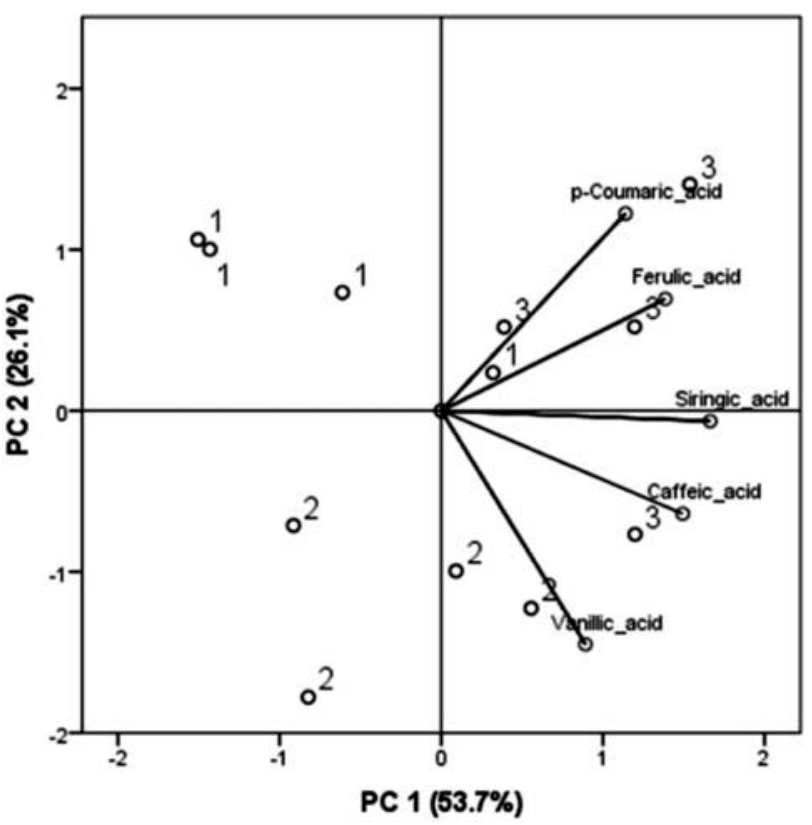

Figure 3. PCA biplot displaying the position of wine samples and descriptors in the plane PC 2 vs. PC 1 for twelve Slovenian red wines. The objects were lebelled by the wine variety.

\section{1. 2. Cluster Analysis (CLU)}

Cluster analysis (CLU) is one of the unsupervised multidimensional procedures that involve measuring the distances or similarities between the objects (or variables) to be clustered.$^{40}$ In the present work, agglomerative hierarchical cluster (AHC) analysis was performed in order to classify the wines tested according to variety type or wine region. Dissimilarities between the samples were determined based on the squared Euclidean distance, and the objects were clustered using Ward's method. A CLU dendrogram is presented in Figure 4. and suggests three groups of clusters. The first cluster group consisted of wine marked as SW2, SW4, SW8 and SW9. All of these wines belong to the Modri Pinot and Modra Frankinja varieties. Samples marked as SW1, SW3, SW5 and SW6 comprised the second group of wines. Three of these wine samples belong to the Cabernet-Sauvignon variety, and sample SW6 belongs to the Refošk variety. All were produced in the Littoral region. Samples marked as SW7, SW10, SW11 and SW12 comprise the third cluster. These results are in accordance with those observed using PCA, 


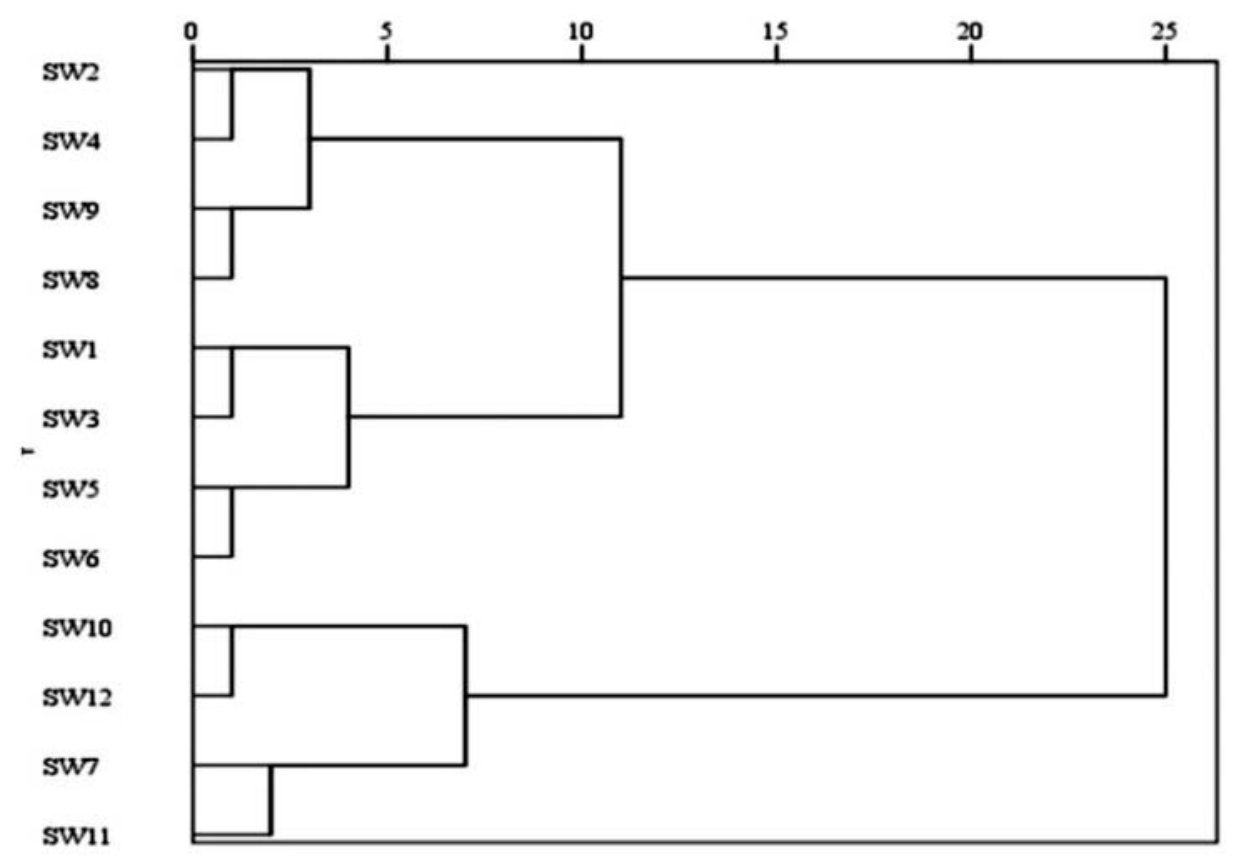

Figure 4. Dendrogram constructed with minimum linkage method for twelve Slovenian red wines.

and confirm that variety has more influence than wine regions on the content of PAs in Slovenian red wines.

\section{Conclusions}

A simple SPE extraction technique for the isolation of PAs from red wine samples was introduced. The SPE technique allows good separation of target compounds and almost complete removal of matrix influence. A GCMS method for the identification and quantitative determination of five selected phenolic acids, together with their isomers, was developed. The method was validated with linearity, precision as repeatability, limit of detection and limit of quantitation. The GC-MS method proposed in this study was successfully applied to characterization of Slovenian red wines according to PAs content. From these results it can be concluded that caffeic acid and $p$-coumaric acid are the most important part of total PAs, with contents varying from 17 to $72 \mathrm{mg} \mathrm{L}^{-1}$. The highest contents of all of the PAs investigated were found in wine samples from the Posavje wine region (SW2, SW10 and SW12). Among those wines exist the correlation in the variety. Namely, sample SW12 (Metliška črnina) is a specific wine variety consisting of Modra Frankinja (SW2), Portugalka (SW10), Žametovka and Šentlovrentka varieties. The concentrations of free and bound PAs in Slovenian red wines were between $0.03-11.8 \mathrm{mg}$ $\mathrm{L}^{-1}$ and 3.8-71.9 $\mathrm{mg} \mathrm{L}^{-1}$, respectively. In accordance with the data obtained using statistical analysis and chemometric methods (PCA and CLU), it can be concluded that variety has more influence on the PA content of Slove- nian red wines, but the influence of wine region cannot be completely ignored.

\section{References}

1. V. Ivanova-Petropulos, A. Ricci, D. Nedelkovski, V. Dimovska, G.P. Parpinello, A. Versari, Food Chem. 2015, 171, $412-$ 420. http://dx.doi.org/10.1016/j.foodchem.2014.09.014

2. I. Mudnic, D. Modun, V. Rastija, J. Vukovic, I. Brizic, V. Katalinic, B. Kozina, M. Medic-Saric, M. Boban, Food Chem. 2010, 119, 1205-1210. http://dx.doi.org/10.1016/j.foodchem.2009.08.038

3. E. F. Gris, F. Mattivi, E. A. Ferreira, U. Vrhovsek, D. W. Filho, R. C. Pedrosa, M. T. Bordignon-Luiz, J. Food Compost. Anal. 2013, 31, 31-40.

4. M. V. S. S. T. Subba Rao, G. Muralikrishna, Food Chem. 2002, 50, 889-892. http://dx.doi.org/10.1021/jf011210d

5. V. Georgiev, A. Ananga, V. Tsolova, Nutrients 2014, 6 , 391-415. http://dx.doi.org/10.3390/nu6010391

6. D. Serrano-Lourido, J. Saurina, S. Hernández-Cassou, A. Checa, Food Chem. 2012, 135, 1425-1431. http://dx.doi.org/10.1016/j.foodchem.2012.06.010

7. X. Sun, L. Li, T. Ma, F. Zhao, D. Yu, W. Huang, J. Zhan, Innov. Food Sci. Emerg. 2015, In Press, Corrected Proof.

8. R. Van Leeuw, C. Kevers, J. Pincemail, J.O. Defraigne, J. Dommes, J. Food Compost. Anal. 2014, 36, 40-50.

9 . I. Garaguso, M. Nardini, Food Chem. 2015, 179, 336-342. http://dx.doi.org/10.1016/j.foodchem.2015.01.144

10. M. J. Rodríguez Vaquero, M. R. Alberto, M. C. Manca de Nadra, Food Control 2007, 18, 587-593. http://dx.doi.org/10.1016/j.foodcont.2006.02.005 
11. S. Q. Liu, J App Microbiol 2002, 92, 589-601. http://dx.doi.org/10.1046/j.1365-2672.2002.01589.x

12. F. M. Campos, A. R. Figueiredo, T. A. Hogg, J. A. Couto, Food Microbilo 2009, 26, 409-414. http://dx.doi.org/10.1016/j.fm.2009.01.006

13. M. R. Alberto, M. E. Farias, M. C. Manca de Nadra, J Agric Food Chem 2001, 49, 4359-4363. http://dx.doi.org/10.1021/jf0101915

14. A. G. Salih, J. M. Le Quéré, J. F. Drilleau, Sci Aliment 2000, 20, 537-560. http://dx.doi.org/10.3166/sda.20.537-560

15. F. M. Campos, J. A. Couto, A. R. Figueiredo, I. V. Tóth, A. O. S. S. Rangel, T. A. Hogg, Int J Food Microbiol 2009, 135, 144-151. http://dx.doi.org/10.1016/j.ijfoodmicro.2009.07.031

16. V. S. Šelih, M. Šala, V. Drgan, Food Chem. 2014, 153, 414423. http://dx.doi.org/10.1016/j.foodchem.2013.12.081

17. V. Weingerl, M. Strlič, D. Kočar, Acta Chim. Slov. 2009, 56, 698-703.

18. M. Ayoub, A. Costa de Camargo, F. Shahidi, Food Chem. 2016, 197, 221-232. http://dx.doi.org/10.1016/j.foodchem.2015.10.107

19. M. A. Harish Nayaka, U. V. Sathisha, S. M. Dharmesh, Food Chem. 2010, 119, 1307-1312. http://dx.doi.org/10.1016/j.foodchem.2009.08.044

20. H. Ti, Q. Li, R. Zhang, M. Zhang, Y. Deng, Z. Wei, J. Chi, Y. Zhang, Food Chem. 2014, 159, 166-174. http://dx.doi.org/10.1016/j.foodchem.2014.03.029

21. N. Ahmad, Y. Zuo, X. Lu, F. Anwar, S. Hameed, Food Chem. 2016, 190, 80-89. http://dx.doi.org/10.1016/j.foodchem.2015.05.077

22. M. P. Germanò, V. D'Angelo, T. Biasini, R. Sanogo, R. De Pasquale, S. Catania, J. Ethnopharmacol. 2006, 105, 368373. http://dx.doi.org/10.1016/j.jep.2005.11.029

23. K. H. Kim, R. Tsao, R. Yang, S. W. Cui, Food Chem. 2006, 95, 466-473. http://dx.doi.org/10.1016/j.foodchem.2005.01.032

24. K. A. Ross, T. Beta, S. D. Arntfield, Food Chem. 2009, 113, 336-344. http://dx.doi.org/10.1016/j.foodchem.2008.07.064

25. E. Xu, Z. Wu, J. Long, F. Wang, X. Xu, Z. Jin, A. Jiao, J. Funct. Foods 2015, 17, 214-226. http://dx.doi.org/10.1016/j.jff.2015.05.032

26. Y. Amakura, M. Okada, S. Tsuji, Y. Tonogai, J. Chromatogr. A 2000, 891, 183-188.
http://dx.doi.org/10.1016/S0021-9673(00)00625-7

27. M. N. Irakli, V. F. Samanidou, C. G. Biliaderis, I. N. Papadoyannis, Food Chem. 2012, 134, 1624-1632. http://dx.doi.org/10.1016/j.foodchem.2012.03.046

28. D. Sun, L. Dong, P. Guo, X. Shi, J. Gao, Y. Ren, X. Jiang, W. Li, C. Wang, Q. Wang, Food Chem. 2013, 138, 139-147. http://dx.doi.org/10.1016/j.foodchem.2012.09.096

29. V. Weingerl, M. Strlič, D. Kočar, Anal. Lett. 2011, 44, 1310-1322. http://dx.doi.org/10.1080/00032719.2010.512674

30. M. Islamčević Razboršek, J. Pharm. Biomed. Anal. 2011, 55, 1010-1016.

http://dx.doi.org/10.1016/j.jpba.2011.04.003

31. L. Minuti, R. M. Pellegrino, I. Tesei, J. Chromatogr. A 2006, 1114, 263-268. http://dx.doi.org/10.1016/j.chroma.2006.02.068

32. M. Saitta, S. Lo Curto, F. Salvo, G. Di Bella, G. Dugo, Anal. Chim. Acta 2002, 466, 335-344. http://dx.doi.org/10.1016/S0003-2670(02)00572-X

33. D. Allen, A. Duyen Bui, N. Cain, G. Rose, M. Downey, Anal. Bioanal. Chem. 2013, 405, 9869-9877. http://dx.doi.org/10.1007/s00216-013-7405-0

34. M. S. García-Falcón, C. Pérez-Lamela, E. Martínez-Carballo, J. Simal-Gándara, Food Chem. 2007, 105, 248-259. http://dx.doi.org/10.1016/j.foodchem.2006.11.006

35. M. Nardini, E. Cirillo, F. Natella, D. Mencarelli, A. Comisso, C. Scaccini, Food Chem. 2002, 79, 119-124. http://dx.doi.org/10.1016/S0308-8146(02)00213-3

36. A. Bimpilas, D. Tsimogiannis, K. Balta-Brouma, T. Lymperopoulou, V. Oreopoulou, Food Chem. 2015, 178, 164-171. http://dx.doi.org/10.1016/j.foodchem.2015.01.090

37. S. Perez-Magarino, M. Ortega-Heras, E. Cano-Mozo, Food Chem. 2008, 56, 11560-11570. http://dx.doi.org/10.1021/jf802100j

38. V. M. Burin, S. G. Arcari, L. L. F. Costa, M. T. BordignonLuiz, J. Chromatogr. Sci. 2011, 49, 647-651. http://dx.doi.org/10.1093/chrsci/49.8.647

39. R. Sladkovský, P. Solich, M. Urbánek, J. Chromatogr. A 2004, 1040, 179-184. http://dx.doi.org/10.1016/j.chroma.2004.04.009

40. A. Bednarova, R. Kranvogl, D. Brodnjak Vončina, T. Jug, E. Beinrohr, Acta Chim. Slov. 2013, 60, 274-286.

\section{Povzetek}

Izbrane fenolne kisline: kavno, vanilinsko, siringinsko, kumarinsko in ferulno smo v različnih rdečih slovenskih vinih analizirali z uporabo GC-MS. Za izolacijo smo uporabljali ekstrakcijski postopek na HLB SPE kolonicah, ki vsebuje hidrofilno modificiran stiren. Pri delu smo vezane fenolne kisline hidrolizirali, kot interni standard pa smo uporabljali orto- kumarinsko kislino. Razvito metodo smo validirali: linearno koncentracijsko območje fenolnih kislin je med 1 in $100 \mathrm{mg} \mathrm{L}^{-1}$, korelacijski koeficienti so bili nad 0,999. Potrdili smo dobro ponovljivost, RSD je znašal pod $2 \%$, izkoristke nad 96\% in sprejemljive vrednosti LOD ter LOQ. Ugotovili smo, da sta v vzorcih slovenskih vin prevladujoči fenolni spojini kavna in para-kumarna kislina (17-72 $\left.\mathrm{mg} \mathrm{L}^{-1}\right)$, medtem ko ostale spojine najdemo v nižjem koncentracijskem območju. Metodo glavnih osi (PCA) in analizo klastrov (CLU) smo uporabili za študij podobnosti in razlik med vzorci glede vsebnosti in deležev fenolnih kislin. Potrdili smo korelacijo in večji vpliv sorte grozdja kot vinorodne dežele oziroma regije, iz katere vzorci vin izvirajo. 